\title{
O estrangeiro de Maurice Blanchot
}

MAURICE BLANCHOT'S StRANGER

Davi Andrade Pimentel

ORCID 0000-0001-5519-3792

Universidade Federal do Rio de Janeiro

Rio de Janeiro, RJ, Brasil

\section{Resumo}

Com base na leitura da narrativa "L'idylle", do escritor francês Maurice Blanchot, este artigo analisa a figura do estrangeiro e as cinco principais características que o definem como aquele ser que vem de fora: a tragicidade de seu destino, a hospitalidade que evoca, a desordem que realiza, o suplício que incita e a morte que finaliza a sua trajetória.

Palavras-chave: estrangeiro; "L'idylle"; Maurice Blanchot; tragédia; desordem.

\begin{abstract}
Based on the reading of "L'idylle", a work by the French writer Maurice Blanchot, this article analyzes the figure of the foreigner and the five main traits that define it as one who comes from outside: the tragicness of its destiny, the hospitality it evokes, the mayhem it causes, the torment it incites and the death that puts an end to its journey.
\end{abstract}

Keywords: foreigner; "Lidylle"; Maurice Blanchot; tragedy; mayhem.

\section{Resumen}

Con base en la lectura de la narrativa "L'idylle", del escritor francés Maurice Blanchot, este artículo analiza la figura del extranjero y las cinco principales características que lo definen como aquel ser que viene de fuera: la tragicidad de su destino, la hospitalidad que evoca, el desorden que realiza, el suplicio que incita y la muerte que finaliza su trayectoria.

Palabras-clave: extranjero; "L'idylle"; Maurice Blanchot; tragedia; desorden. 
Du fond de mon avenir, pendant toute cette vie absurde que javais menée, un soufle obscur remontait vers moi à travers des années qui n'étaient pas encore venues et ce souffle égalisait sur son passage tout ce qu'on me proposait alors dans les années pas plus réelles que je vivais. Albert Camus. L'étranger.

Le ciel était déjà plein de soleil. Il commençait à peser sur la terre et la chaleur augmentait rapidement. Albert Camus. L'étranger.

Em "Lidylle", ${ }^{1}$ como é próprio dos personagens de Maurice Blanchot, cujas características principais são a chegada a e o chamado a, aquele (ainda sem nome) que chega à cidade (desconhecida) por meio de um chamado (desconhecido ou inexistente) não poderia se esquivar desse destino destino predeterminado por aquele que é a gênese de todos os personagens blanchotianos, Thomas, o obscuro: "Thomas observou por sua vez esse fluxo de imagens grosseiras, depois se precipitou nele tristemente, desesperadamente, como se a vergonha tivesse começado por ele." (BLANCHOT, 1941, p. 323), ${ }^{2}$ herança-escrita destinada a fazer fracassar os seus herdeiros. Walter Benjamin, em seu texto "Franz Kafka: a propósito do décimo aniversário de sua morte", presente no livro Magia e técnica, arte e politica, conduz um pensamento sobre a obra kafkiana que poderia ser extensivo à obra ficcional blanchotiana - refiro-me à sina do pecado original que condena os personagens de Kafka, sobretudo os de seus romances, a um destino de perdas, frustraçóes, errância indefinida e morte:

No mundo primitivo, as leis e normas prescritas permanecem não escritas. O homem pode transgredi-las sem o saber, incorrendo assim em pecado. Contudo, por mais dolorosamente que elas afetem o ignorante, sua intervenção, no sentido jurídico, não é acaso, mas destino, o qual se apresenta aqui em toda a sua ambiguidade.

(BENJAMIN, 2012, p. 150)

Nessa perspectiva, Kafka traz o elemento trágico às suas narrativas, quando transforma o seu personagem em um herói trágico moderno e negativo,

1 A narrativa "Lidylle", juntamente com a narrativa "Le dernier mot", pertence ao livro Après coup précédé par Le Ressassement éternel (1983).

2 Todas as traduçôes das obras em francês citadas são de autoria do autor deste artigo. 
sem liberdade alguma diante de seu destino ordenado antecipadamente por uma divindade-escrita desconhecida: "O que acontece com a tragédia no século XX não é a sua morte, mas sua transformação em modernismo. [...] E se o modernismo confere vida nova ao impulso trágico é sobretudo por causa do retorno da mitologia." (EAGLETON, 2013, p. 285). Na modernidade, o não saber, a alienação, o negativo e o desconhecido, próprios da tragédia clássica, conquistam um cenário moderno, não mais nobre ou palaciano, mas sim fétido, periférico e vilipendiado, no qual a ação trágica transcorre, por exemplo, em quartos abjetos, em cidades opressoras e sujas, em asilos, em lugares totalmente desinvestidos de beleza ou de um futuro próspero e belo. Assim são os cenários kafkianos e blanchotianos. E o tempo, enquadrado pelo destino mítico, comprime esses cenários provocando uma sensação de angústia inescapável no personagem e em seu leitor: "Esta mesma composição encontramos no tempo, que não só é despido de sua força criadora como tem algo de inumano. Uma providência má faz por danar os homens já de si impotentes." (SCHWARZ, 1981, p. 62, grifo do autor). Roberto Schwarz, em "Uma barata é uma barata é uma barata", presente em $A$ sereia e o desconfiado, arremata: "Por ter conteúdos prefigurados, o tempo mítico não guarda lugar para a liberdade." (SCHWARZ, 1981, p. 64). Gregor Samsa, personagem de A metamorfose, e Karl Rossmann, personagem de O desaparecido ou Amerika, são fortes exemplos de como o destino prefigurado e o tempo mítico não lhes permitem uma liberdade para além do que já antes lhes fora traçado: a metamorfose em inseto e a morte pelo pai, em Gregor, e o destino para sempre frustrante, em Karl. Aos personagens kafkianos, marcados por um pecado original totalmente desconhecido por eles, somam-se os personagens das narrativas de Blanchot.

Neste artigo, a relação entre Blanchot e Kafka não é aleatória, e muito menos gratuita. Em seus escritos críticos sobre literatura, Blanchot já afirmou diversas vezes que, caso quiséssemos entender o que seja literatura, bastaria lermos as obras kafkianas: "Temos às vezes a impressão de que Kafka nos oferece uma chance de entrever o que é a literatura." (BLANCHOT, 1997, p. 19). Kafka marcou tanto o pensamento crítico de Blanchot, quanto os seus textos ficcionais. Dentre os mais kafkianos, está Aminadab, cuja estrutura narrativa é labiríntica e sufocante, com açóes que não resultam afirmativas, mas sempre negativas, cuja lei que se apresenta enquanto presença-ausência e cujos objetivos tendem constantemente a fracassar são exemplos de uma re-leitura blanchotiana dos recursos literários de Kafka. Vale destacar que não se trata de uma cópia menor e inferior do mundo ficcional kafkiano, como afirma Jean-Paul Sartre, em "Aminadab, ou o fantástico considerado como uma linguagem”, texto presente em Situaçôes I, mas de um recurso de tradução, tradução no sentido de re-criação, que consequentemente produz novos textos: 
"Nunca se traduz: se re-escreve, se re-cria, se re-faz a obra." (SHAHRJERDI, 2009 , p. 148). Nesse processo de re-escrita, aquele que chega à cidade em "L'idylle" re-encena a chegada do agrimensor K., de $O$ castelo, mas logo depois subverte a lógica da escrita que lhe deu origem, construindo, a partir de então, um caminho próprio narrativo, que o levará a uma composição única de sua ficção. Eis a primeira frase da narrativa "Lidylle": "Mal entrou na cidade, o estrangeiro foi conduzido ao asilo." (BLANCHOT, 1983, p. 09). Há, de início, um elemento trágico, o destino, na composição de abertura da narrativa blanchotiana em questáo que não encontramos no começo de $O$ castelo: "Era tarde da noite quando K. chegou." (KAFKA, 2000, p. 09). Em "Lidylle", a tragicidade, como veremos, está na prisão do estrangeiro sem as provas do crime que possivelmente cometera, sendo-lhe, assim, confiscada a liberdade que antes tivera, como se o seu destino de prisioneiro estivesse selado ao chegar à cidade desconhecida.

O guarda, que o deteve à entrada da cidade, aconselha-o por meio de palavras cifradas, semelhante a um oráculo que pressagia o futuro: "Agora, vou embora, disse-lhe o guarda em voz baixa. Mas lhe peço, siga meu conselho: não confie nas aparências." (BLANCHOT, 1983, p. 09). Desse conselho, o estrangeiro somente se dará conta de sua real importância ao final de sua tragédia, quando de sua morte: "Akim ainda estava vivo quando caiu das mãos do carrasco." (BLANCHOT, 1983, p. 53). Se, por um lado, como confirma Terry Eagleton, em Doce violência: a ideia do trágico, nem todas as tragédias terminam em morte ou com um sofrimento extremo de seu herói; por outro lado, o sofrimento e a morte são inerentes ao drama trágico, seja ele clássico ou moderno: "Elas [as tragédias] não compartilham de qualquer essência, exceto no aspecto do sofrimento; mas o sofrimento é uma linguagem extremamente poderosa para se compartilhar." (EAGLETON, 2013 , p. 20). E a morte, como veremos a seguir, possui um valor simbólico, no qual a destruição do ser vem a se tornar uma espécie de compreensão de si, do outro e do mundo. Em seu caminho para a morte e em sua condenaçáo nonsense, o destino do estrangeiro blanchotiano se aproxima uma vez mais do mundo kafkiano, agora, de Josef K., de $O$ processo: "Alguém certamente havia caluniado Josef $K$. pois uma manhã ele foi detido sem ter feito mal algum.” (KAFKA, 1997, p. 09). Caso o leitor ainda não tenha percebido, a primeira frase da narrativa "L'idylle" é uma convergência a um só tempo das primeiras frases de $O$ castelo, "a chegada de K", e de $O$ processo, "a detenção sem justa causa de Josef K.”. Através dessa convergência, Blanchot opera uma ressignificação da escrita kafkiana, modulando-a com base na necessidade de sua estrutura ficcional, o que resultará por fim em uma escrita blanchotiana assombrada constantemente pela presença, embora ausente, do espectro do escritor tcheco. Ao chegar ao asilo, Louise, que administra a instituição 
com o seu marido Pierre, logo impóe ao estrangeiro (sem nome) o nome de Alexandre Akim, que, para o estrangeiro, é um nome estranho/estrangeiro que nada significa e com o qual não mantém nenhuma relação de intimidade: "Esse nome estranho lhe convinha tão bem quanto qualquer outro: ele aqui era somente uma espécie de mendigo.” (BLANCHOT, 1983, p. 12).

O asilo

Tout de suite après mon arrestation, jai été interrogé plusieurs fois. Mais il s'agissait d'interrogatoires d'identité qui n'on pas duré longtemps. Albert Camus. L'étranger.

Talvez o seu único crime tenha sido o fato de ser estrangeiro: “- De onde você é? perguntou-lhe o velho se acocorando ao seu lado. / - Então, você também espiona, respondeu desdenhosamente. Será que isso conta, que eu seja de um país em vez de um outro? Sou estrangeiro, ponto final." (BLANCHOT, 1983, p. 12). O não há resposta obtido pelo velho sinaliza para aquilo que Jacques Derrida, em De l'hospitalité, introduzirá como o problema central da questão da hospitalidade: "Antes de dizer a questão do estrangeiro, talvez fosse necessário precisar: questão do estrangeiro." (DERRIDA, 1997, p. 11, grifo do autor). Segundo Derrida, os impasses produzidos pelo estrangeiro não são conhecidos pelos habitantes de um local até a sua chegada, ou melhor, as questóes provocadas pela aparição do estrangeiro somente podem irromper através do estrangeiro, jamais podendo antecedê-lo, pois o estrangeiro é, ele próprio, a questão. Nesses termos, o significado da presença do estrangeiro é resultante do estrangeiro enquanto significante, sendo por meio dele que o significado de suas implicaçóes pode adquirir um determinado valor, seja esse valor negativo ou positivo. Ao dizer ao velho: "Sou estrangeiro, ponto final.", o estrangeiro de Blanchot reafirma a potência de sua presença de estrangeiro, repudiando todo e qualquer elemento anterior à sua chegada, uma vez que ser estrangeiro é não ter passado, mas um contínuo presente de exílio: “- É um estrangeiro, disse Louise alegremente. Sempre pensei nisso, ele nunca se tornará um homem daqui." (BLANCHOT, 1983, p. 31). Uma das implicaçóes mais trágicas da presença do estrangeiro é a sua desordem: o estrangeiro é aquele que, por ser o elemento estranho, tende a corromper os elementos dispostos ordenadamente de um local. Por ser proveniente de uma ordem da qual nada sabemos, dépaysé, o estrangeiro obedece apenas a lei de sua estrangeiridade, instigando, com isso, movimentos de repressão por parte daqueles que sáo responsáveis pela ordem do local, como, por exemplo, Louise e Pierre, os responsáveis pela salvaguarda da ordem do asilo: "O estrangeiro, o suplicante, perturbam o homem do lar, até mesmo o mais 
poderoso.” (BLANCHOT, 2007, p. 24). Após seguidas infraçóes, Pierre julga o estrangeiro e sentencia-lhe a pena, dez golpes de chicote:

- Você se tornou culpado de uma deplorável ação, disse-lhe aquele [Pierre] com um ar desolado. Você enganou uma moça ao lhe propor casamento, enquanto você só sonhava em desaparecer. Você nos enganou nos fazendo relaxar nossa vigilância, sob pretexto das bodas que era preciso preparar. Você perturbou a ordem da casa. Você vê um meio de escapar do castigo?

(BLANCHOT, 1983, p. 51-52)

Em sua chegada, o estrangeiro traz a desordem e, como bem destaca Derrida, a pergunta terrível: "O Estrangeiro leva e coloca a questáo perigosa" (DERRIDA, 1997, p. 17). Uma questáo que coloca em questão a ordem estabelecida do local, pois a sua presença estrangeira não apenas perturba a ordem, como tende a escancarar a sua falsa harmonia, a sua falsa moralidade baseada em instituiçóes de antemáo fracassadas, como, por exemplo, o casamento: "Durante a refeição que ela própria serviu, a moça [Louise], os olhos vivos, a face brilhante, não parou de dar voltas em torno do estrangeiro. Mas foi quando ele terminou que ela pegou em sua mão lhe perguntando: 'O que você pensa de meu marido?' $\mathrm{O}$ estrangeiro recebeu essa pergunta como um choque." (BLANCHOT, 1983, p. 12). Em "L'idylle", como em Thomas l'obscur, Aminadab, La folie du jour, Celui qui ne m'accompagnait pas, Au moment voulu, L'arrêt de mort e Le dernier homme, aquele que traz o Mal, refiro-me aqui ao Mal de Bataille de $A$ literatura e o $m a l,{ }^{3}$ não se dá conta inicialmente de sua potencialidade destruidora da ordem e da lei, como se, na verdade, estivesse alienado a respeito de sua própria potência, como é o caso deste estrangeiro de Blanchot. Esses personagens erram por suas narrativas destruindo tudo o que tocam, como reis Midas da destruição, embora somente se deem conta desse fato ao final de seu texto, por meio da morte, da desilusão, do fracasso ou do término de sua escrita - o ponto final e/ou as reticências modulam essa compreensão tardia do fato de serem eles os causadores do Mal de suas narrativas. Cito dois exemplos: o primeiro, as últimas linhas de Celui qui ne m’accompagnait pas: "Toda a força do dia teve que se estender, alcançar esse fim, e talvez ele [o personagem] responda logo, mas quando o fim chegou, após o espraiamento de alguns segundos, tudo já tinha desaparecido, desaparecido com o dia." (BLANCHOT, 1953, p. 174); o segundo, o final de Au moment voulu: "Posso me lembrar de tudo isso, e me lembrar, isso é sem dúvida um passo a mais no mesmo espaço, ali onde ir mais longe é já me ligar à volta. E, no entanto, embora o círculo já

3 A seguir, na próxima seção deste artigo, será discutida com mais profundidade a questão do Mal na perspectiva de Bataille. 
me arraste, e mesmo se me fosse preciso escrevê-lo eternamente, escrevê-lo-ia para apagar o eterno: Agora, o fim.” (BLANCHOT, 1979, p. 166).

Apesar do caos obedecer à presença do estrangeiro, nem ele próprio sabe que o carrega dentro de si como uma bomba-relógio pronta a explodir. Apenas no instante da explosão, quando a ordem do lugar vacila, é que o estrangeiro se dá conta de que carrega o caos em suas açóes, pensamentos e palavras: "Pierre avançou em direção ao estrangeiro e, após estar próximo dele até tocá-lo: 'É um idílio? disse-lhe ele. É mesmo um idílio?' [...] Akim deixou lentamente o quarto, mas, antes de fechar novamente a porta, disse enfim a Pierre: - Um idílio? Sim, por que não?” (BLANCHOT, 1983, p. 44). Um idílio construído a partir da instituição do casamento, e da representação deste como exemplo de ordem para toda a cidade, uma ordem a ser seguida: “- Bem, acredito que o casamento deles [de Pierre e de Louise] tem sido um verdadeiro idílio. Raramente encontrei unióes tão perfeitas." (BLANCHOT, 1983, p. 40). Para aqueles que habitam a cidade, o asilo figura como a instituição máxima, como a Lei que dita os costumes, a moral e a política, como o Bem em detrimento do Mal, do caos. Em termos geográficos, "L'idylle" apresenta um fato interessante: o asilo está ladeado pelo cemitério, ou seja, a saída do asilo, para aqueles que estão presos, se dá por duas vias: pelo casamento ou pela morte. E das duas vias, o destino já se encarregara de escolher a que melhor convinha ao estrangeiro: a morte. Apesar de, em um primeiro momento, o estrangeiro ter cogitado a liberdade pela via do casamento, tal possibilidade apresentou-se impossível para ele, uma vez que a ordem (o casamento) náo pode coabitar o mesmo espaço da desordem (o estrangeiro), semelhante ao que ocorre a Abel (a ordem e o escolhido) e a Caim (a desordem e o preterido), na leitura de Blanchot do episódio bíblico em "Manter a palavra", texto presente em $A$ conversa infinita 1 - a palavra plural:

- É que para Caim, o obstáculo que é a presença infinita de Abel é como uma coisa que pertence efetivamente a Abel e da qual ele tem que ser privado. Em certo sentido, isso não é falso: esta presença é também a feliz fortuna de Abel, a benção, o rebanho que se multiplica. Desde que a presença do outro em outrem não é acolhida pelo eu como o movimento pelo qual o infinito vem a mim, desde que esta presença se encerra em outrem como propriedade de outrem, estabelecido no mundo, desde que ela cessa de propiciar a palavra, a terra deixa de ser vasta o suficiente para poder conter ao mesmo tempo outrem e eu, e é preciso que um dos dois rejeite o outro - absolutamente.

(BLANCHOT, 2001, p. 112)

Em "Conhecimento do desconhecido", texto também presente no livro citado anteriormente, Blanchot dialoga cerradamente com Emmanuel Levinas sobre o abismo que existe entre o eu e o outro, destacando que o 
lugar do outro é aquele do estrangeiro: "O Estrangeiro vem de outro lugar e nunca está onde estamos, não pertence a nosso horizonte e não aparece em nenhum horizonte representável, de forma que o invisível seria o seu 'lugar', entendendo com isto [...] o que se desvia de todo o visível e de todo invisível." (BLANCHOT, 2001, p. 99). Levinas, em Le temps et l'autre, confirma essa intangibilidade do outro-estrangeiro: "A relação com o outro não é uma idílica e harmoniosa relação de comunháo, nem uma simpatia pela qual nos pondo em seu lugar o reconhecemos como semelhante a nós, mas exterior a nós; a relação com o outro é uma relação com um Mistério." (LEVINAS, 2011, p. 63, grifo meu). Por ser aquele que náo pode ser identificado, embora a ordem deseje fazê-lo, por ser aquele que se desvia de nós e por ser aquele de quem nada sabemos, pois misterioso, o estrangeiro de Blanchot jamais poderia se submeter à ordem através do matrimônio com a filha do velho que anteriormente lhe indagara sobre a sua origem, sendo "preciso que um dos dois rejeite o outro - absolutamente." (BLANCHOT, 2001, p. 112). Se a via do casamento lhe é interdita, resta-lhe a via da morte, desde sempre predestinada a ele. Em "L'idylle", a via para a morte toma duas direçóes, uma metafórica e outra literal. A primeira direção: após ter visualmente gravado o mapa da cidade, o estrangeiro resolve partir em fuga, tendo que passar pelo cemitério para recuperar a sua liberdade, uma passagem, digamos, metafórica de sua morte futura: "Logo, ele percebeu o cemitério. O seu muro era intransponível; as portas resistiam à sua pressão. Contudo, era preciso atravessar a esplanada, pois ele náo sabia até onde se estendia o pântano e só havia um caminho seguro através das sepulturas." (BLANCHOT, 1983, p. 50). A segunda direção: como não poderia escapar de seu destino para a morte, no qual o tempo mítico de sua narrativa não lhe permitiria nenhuma liberdade fora daquela já prevista de antemão por sua escrita, o estrangeiro náo consegue chegar à fronteira da cidade, sendo acometido de grande cansaço após errar sem esperança pelo labirinto de suas ruas e vielas: "Depois de ter errado sem esperança, Akim chegou a uma vasta avenida cercada por grandes árvores tranquilas. Talvez fosse o fim da cidade, talvez fosse o começo de uma nova vida, mas, como estava arrasado de cansaço, ele caiu, e um guarda desde a primeira hora o acompanhou ao asilo." (BLANCHOT, 1983, p. 51).

A resposta a essa fuga é a punição: dez chicotadas em um tablado localizado no centro do asilo, no qual o seu corpo violado, como veremos, será materialmente dado como exemplo para aqueles que desejam ou pensam em infringir a ordem do asilo - um espetáculo de exemplaridade, como dirá Michel Foucault, em Vigiar e punir: "Pronto, está acabado, disse o diretor. Estou contente de ver que tudo acabou bem. Não há mais razão para voltar a esse assunto." (BLANCHOT, 1983, p. 53-54). A esse destino de morte, o estrangeiro não pudera escapar, uma vez que ele seria a questão necessária 
que abalaria as falsas e corrompidas fundaçóes da ordem instituída pelo asilo para si e para a cidade como um todo, ordem que, como uma doença, estava corrompendo o sistema orgânico da cidade e dos seus cidadãos: "De manhã, a atmosfera da cidade era leve e como que renovada pela noite; e no entanto, à noite, uma espécie de veneno saía da terra, mais pesado, mais carregado de pestilência do que aquele dos grandes pântanos." (BLANCHOT, 1983, p. 44-45). Como Édipo, o estrangeiro teve como destino libertar a cidade das calamidades promovidas e perpetuadas pela Esfinge-asilo. A libertação da cidade somente poderia se dar com a sua morte, ao desmascarar a ordem e colocar em questão o seu ardil mais empregado - o casamento: "Por que você me obrigou a tomar tal medida? Quem o aconselhou a essa fuga? Você não ia ficar livre? Pense nessa moça que, desde ontem, espera-o." (BLANCHOT, 1983, p. 52).

O Mal

Je promenais toute la journée une nausée perpétuelle. Je ne comprenais pas pourquoi on me privait de cela qui ne faisait de mal à personne. Plus tard, j'ai compris que cela faisait partie aussi de la punition. Albert Camus. L'étranger.

Outro oráculo, o velho que o per-segue constantemente no asilo, já antes o prevenira sobre a fraude da ordem: "- Escute, disse-lhe o velho empurrando-o para um canto, você já percebeu isso, o diretor e sua mulher se odeiam. É um ódio silencioso, sem motivo, um sentimento terrível que estremece a casa e que não tem necessidade de nenhuma violência para se exprimir." (BLANCHOT, 1983 , p. 20, grifo meu). Mas, do mesmo modo como ocorreu diante do primeiro oráculo, do guarda, o estrangeiro não lhe dera ouvidos; somente ao fim de sua tragédia é que ele tomará ciência da sabedoria dos oráculos e compreenderá o seu destino: “- Espero seu julgamento, murmurou Akim. I - Meu julgamento depende de sua infração, disse o diretor. Você receberá dez golpes de chicote. / Akim observou-o sem dizer nada." (BLANCHOT, 1983 , p. 52). O mal do qual o estrangeiro liberta a cidade é plenamente diferente do Mal do qual ele próprio é o representante. Nesta leitura, entre o mal e o Mal, Blanchot entra em profundo diálogo com Georges Bataille. Em A literatura e o mal, Bataille, em sua definição do Mal, trata de opôlo ao sentido que a palavra mal adquire comumente em nosso cotidiano: aquilo que macula, que danifica, que oprime, que enfeia e que aterroriza, por exemplo. Em nosso mundo, o mal é aquilo que se opóe ao bem: à ordem, à harmonia, à lei, ao belo, ao puro, ao justo e ao futuro. Contudo, ao trazer o conceito de Mal para a literatura, Bataille desloca o seu caráter negativo 
para o Bem, que, por sua vez, representa a ordem, o projeto, que tende a alienar e a homogeneizar os homens e a arte em geral. O Mal é o que liberta. Ele é a ruptura com a ordem e com a lei. O Mal é o que produz o caráter performático do literário, que rasga os modelos, as poéticas e os manuais. $\mathrm{O}$ Mal é o estrangeiro. E tanto o Mal quanto o estrangeiro são a literatura: " $A$ literatura é o essencial, ou não é nada. O Mal-uma forma aguda do Mal-de que ela é a expressáo tem para nós, acredito, o valor soberano. [...] A literatura não é inocente e, culpada, devia, no fim, confessar-se tal." (BATAILLE, 2015, p. 9, grifo do autor).

Há nesse humor sombrio de Bataille uma verdade: a literatura, diante do Bem, é, sim, culpada, pois visa a todo instante infringi-lo. Ela macula e corrompe a linguagem humana. No espaço literário, a palavra se deixa seduzir pelo Mal, ou seja, deixa-se abrir para a sua verdadeira essência que, segundo o linguista Ferdinand de Saussure, em seu Curso de Linguística Geral, é a arbitrariedade. Em "A literatura e o direito à morte", texto presente em $A$ parte do fogo, Blanchot recorda que a palavra, que táo despreocupadamente utilizamos em nosso dia a dia, não nos entrega o ser referido pelo significante, mas a ausência do ser, uma vez que, para existir a ideia do ser, é preciso que o verdadeiro ser morra, desapareça: "Certamente, minha linguagem não mata ninguém. No entanto: quando digo 'essa mulher', a morte real é anunciada e já está presente em minha linguagem; [...] minha linguagem significa essencialmente a possibilidade dessa destruição." (BLANCHOT, 1997, p. 311, grifo do autor). E o Mal literário vem anunciar que a ideia de imediaticidade entre significante e significado é falsa, sendo preciso desacreditá-la por meio da linguagem poética, onde a linguagem se apresenta em toda a sua arbitrariedade: "A poesia não aceita os dados dos sentidos em seu estado de nudez [...]. Sáo antes os limites precisos dos objetos entre si que ela recusa [...]. Ela nega, e destrói, a realidade próxima porque vê nela a tela que nos dissimula a figura verdadeira do mundo." (BATAILLE, 2015, p. 79). A verdade que a poesia escancara aos homens é que a ordem presente no mundo tem como base a desordem própria do ato de linguagem - linguagem que, como se sabe, é o instrumento utilizado pelos homens para melhor gerir o mundo. Sem a linguagem, não há o homem, nem o mundo, pois o homem e o mundo só passam a existir por meio da linguagem, e esta é traiçoeira: "A palavra não basta para a verdade que ela contém." (BLANCHOT, 1997, p. 314, grifo do autor).

Em "L'idylle", o estrangeiro, enquanto elemento literário, é aquele que vem anunciar o caráter enganoso da ordem representada pelo asilo: "Akim sabia, pela leitura do livrinho, que um detento que se casasse deixava imediatamente o asilo para seguir sua mulher. Mas ele sentiu tamanho horror por tal costume que o recusou secamente." (BLANCHOT, 1983, p. 43). Nessa cidade, que sacrifica o agora (Mal) em favor do porvir (Bem), o 
trabalho (o projeto de futuro) é o meio pelo qual a ordem pode ser revestida de caracteres enobrecedores, bem como é o meio pelo qual o homem pode ser coagido a servir à ordem, tornando-se uma engrenagem de seu maquinário supostamente perfeito: "Imediatamente depois, enviaram-no à pedreira onde ele [o estrangeiro] trabalhou com os companheiros. [...] O trabalho consistia em transportar a um imenso buraco as pedras que arrancavam a cada dia da montanha os operários da cidade." (BLANCHOT, 1983, p. 15). Porém, por ser um elemento de fora, o estrangeiro, aquele que não obra, questiona as leis locais, buscando as devidas razóes para que essas leis tenham sido sancionadas. $\mathrm{Na}$ verdade, as leis existem, desde o começo das eras, para que os instintos mais dispendiosos que habitam o homem, e que nele se encontram latentes, não irrompam. O objetivo do trabalho, como ressalta Bataille, em O erotismo, é poder fazer com que o meio social exista e seja um meio produtivo, e não dispendioso: "Numa palavra, distinguiram-se dos animais pelo trabalho. Paralelamente, impuseram-se restriçóes conhecidas pelo nome de interditos. [...] É provável que tenham tocado ao mesmo tempo - ou à mesma época - a atividade sexual." (BATAILLE, 2014, p. 54, grifo do autor). Com o trabalho, veio a ordem e, consequentemente, os interditos morais, sociais e sexuais. Neste último, enquadra-se o asilo de "L'idylle", táo aficionado pela interdição sexual que faz dela o fundamento de sua existência, de sua Lei. Em um primeiro contato com o estrangeiro, Pierre logo o questiona: "Você é casado? disse ele docemente." (BLANCHOT, 1983, p. 14).

De todas as infraçóes à Lei do asilo, a única imperdoável foi quando o estrangeiro abandonou a futura esposa no altar, ao tentar fugir na noite anterior de seu casamento. Daí a importância do matrimônio à ordem da cidade, a importância da instituição do casamento, que, por sua vez, não deixa de ser uma espécie de interdito sexual aos instintos mais primitivos do homem: "O interdito elimina a violência, e nossos movimentos de violência (entre os quais aqueles que correspondem à impulsão sexual) destroem em nós a calma ordenação sem a qual a consciência humana é inconcebível." (BATAILLE, 2014, p. 61). Ao violar a lei matrimonial, o estrangeiro viola a ordem da cidade, sendo preciso castigá-lo, pois o "Bem se funda na preocupação com o interesse comum, que implica, de uma maneira essencial, a consideração do futuro." (BATAILLE, 2015, p. 19). O comum diferencia-se do individual. Caso todos buscassem o prazer individual, e não o prazer em comum, nenhuma possibilidade de sociedade seria possível. E é exatamente esse resgate do individual, do prazer do agora, do presente enquanto satisfaçáo imediata que reclama o estrangeiro de Blanchot, por isso ele foge do trabalho na pedreira, das obrigaçóes com os recém-chegados e da lei matrimonial. Para ele, os vários instantes de prazer produzidos por sua liberdade confiscada pelos diretores do asilo é o que na verdade lhe interessa: “- Quanto tempo você me manterá 
prisioneiro? perguntou ele [o estrangeiro a Pierre]. / [...] - Desculpe-me, disse Akim, gostaria de dizer: quando poderia deixar o asilo?" (BLANCHOT, 1983, p. 32). Porém, ao aprisionar o estrangeiro e tentar corrigi-lo por meio do trabalho, e depois pelo casamento, o asilo trouxe para dentro da casa aquele que arruinaria as suas fundaçôes: "todo recém-chegado propóe uma verdade que não se deve pôr porta afora; mas, se a acolhemos, quem sabe até onde ela nos conduzirá?" (BLANCHOT, 2007, p. 24). Ao "acolhê-lo", o asilo recebe em troca a verdade trazida pelo estrangeiro: "- Um idílio? Sim, por que não?" (BLANCHOT, 1983, p. 44).

O suplício

Je me reprochais alors de n'avoir pas prêté assez d'attention aux récits d'exécution. On devrait toujours sintéresser à ces questions. On ne sait jamais ce qui peut arriver. Albert Camus. L'étranger.

Devido aos gastos com o casamento anulado e à ânsia dos detentos, dos familiares da noiva e de outros convivas em aproveitar o mais rapidamente possível o que sobrara do repasto do matrimônio fracassado, o castigo do estrangeiro se deu em um hangar náo muito longe de onde se festejaria o seu casamento. Ficou certo que, para não haver desperdícios, após o suplício do estrangeiro, os demais desfrutariam do buffet preparado com tamanha diligência por Louise: "No sexto golpe, ele [o estrangeiro] ouviu as fanfarras que precediam o cortejo e anunciavam a festa." (BLANCHOT, 1983, p. 53). Mas, antes de tudo, era preciso dar o exemplo: "Fazer do culpado, em primeiro lugar, o arauto de sua própria condenação. Ele é encarregado, de algum modo, de proclamá-la e, dessa maneira, de atestar a verdade do que lhe foi reprovado." (FOUCAULT, 2014, p. 45). O estrangeiro foi colocado à vista de todos os presentes em um tablado à maneira de um palco teatral. O seu castigo, dez golpes de chicote, foi transformado em um espetáculo de exemplaridade, como modo de barrar a insubordinação de futuros criminosos, daqueles que, na visão da Lei do asilo, optariam pelo Mal em detrimento do Bem. O carrasco e o estrangeiro, então, desempenham por alguns minutos cenas de grande apelo catártico na plateia ambiguamente nervosa - ora nervosa pelo que os olhos viam, ora nervosa pelo que o estômago avistava nas mesas do buffet. Na construção dessa cena, "Lidylle" tornou-se uma verdadeira tragédia funesta - a festa de casamento que foi substituída por um suplício que resultou na morte da vítima e que, logo depois, foi substituída por um grande festejo, tudo findando em uma alegre comemoração: 
Depois do primeiro golpe, Akim perdeu a consciência; mas, no terceiro, ele voltou a si e sofreu mortalmente. Entre cada golpe era preciso que ele esperasse o carrasco retomar suas forças; ele não sabia se viveria o bastante para receber a morte após uma nova lesão; ele estava ultrajado, humilhado, ameaçado de ser deixado vivo com dores tâo fortes capazes de lhe tirar a vida.

(BLANCHOT, 1983, p. 53)

Em Vigiar e punir, Foucault nos assegura que o suplício, em tempos não tão distantes, não era um simples aparato da justiça para fazer sofrer ou fazer punir o criminoso. Na verdade, configurava-se antes como um meio de exposição do corpo do criminoso e de nele se inscrever a lei do soberano, através de um ritual demorado de flagelaçóes e de inscriçóes no corpo-livro daquele que cometera o crime, pois o "crime, além de sua vítima imediata, ataca o soberano; ataca-o pessoalmente, pois a lei vale como a vontade do soberano; ataca-o fisicamente, pois a força da lei é a força do príncipe." (FOUCAULT, 2014, p. 49). Nessa perspectiva, ao violar a Lei, o estrangeiro violou sobretudo o corpo do asilo representante da Lei, os corpos soberanos de Pierre e de Louise. Em sua narrativa trágica, elementos clássicos de tortura são retomados para dar um maior investimento de exemplaridade no castigo do estrangeiro, como se fosse necessário buscar um respaldo já validado anteriormente, em tempos idos, para que o castigo fosse executado com plena consciência limpa por parte dos administradores do asilo, que tomavam o castigo como um elemento a mais dentro do corpo de instruçóes da Lei. Terminado o castigo, era preciso retornar à normalidade do dia. Nesse sentido, a morte do outro figura como uma morte qualquer para a ordem, pois, para ela, uma peça enferrujada da engrenagem deve ser simplesmente substituída em seu maquinário geral - a peça deve ser jogada fora e nada mais. Há sangue-frio, desprezo pela vida e pelo corpo do outro, sentimento de superioridade sobre o outro supliciado e, principalmente, uma cega crença de triunfo diante da morte do estrangeiro:

Ela [Louise] deu maquinalmente leves pancadinhas em seus joelhos [da exnoiva], depois, após ter observado o céu magnífico e maravilhoso, o céu que, sob o espelho da primavera, unia-a [a ex-noiva] ainda, apesar da morte e das lágrimas, aos reflexos de uma fé inquebrantável, ela se levantou para exercer seus deveres de dona da casa. (BLANCHOT, 1983, p. 56)

Com as inscriçóes da letra da Lei em sua pele fustigada, o estrangeiro cede ao apelo da morte, ao seu destino para a morte. No entanto, antes de morrer, ele executará um movimento final que abalará para sempre as fundaçóes do asilo. Diante do diretor, o estrangeiro, em suas últimas forças, dirige-lhe um derradeiro olhar para lhe assegurar da soberania de sua morte e das consequências resultantes dela para o asilo e para toda a cidade: "-Você 
sofre? acrescentou idiotamente o diretor. Ele observava os olhos escuros do estrangeiro que o fixavam com insistência, sua boca ensanguentada, suas mãos úmidas de suor." (BLANCHOT, 1983, p. 54). De agora em diante, haverá a abertura por onde possa se infringir a ordem. Se, antes, essa abertura não tinha sido levada ao extremo do rasgo, agora, após a chegada do estrangeiro, tal abertura jamais poderá ser remendada, colada e costurada. Com a morte do estrangeiro, fez-se a abertura para a verdadeira face do real: uma nova realidade na qual a ordem está a todo momento sendo questionada pela desordem que lhe é inerente, pois, sendo tudo linguagem, nada pode escapar de sua arbitrariedade essencial: "Na linguagem do mundo, a linguagem cala-se como ser da linguagem e como linguagem do ser, silêncio graças ao qual os seres falam, no qual encontram também esquecimento e repouso." (BLANCHOT, 1987, p. 34).

O morto

J'ai compris que j'avais détruit l'équilibre du jour, le silence exceptionnel d'une plage où j'avais été heureux. Alors j'ai tiré encore quatre fois sur un corps inerte où les balles s'enfonçaient sans quill y parût. Et cétait comme quatre coups brefs que je frappais sur la porte du malheur. Albert Camus. L'étranger.

O corpo morto do estrangeiro selou o seu destino. Um corpo para a morte cujo objetivo era descentrar a ordem e apresentá-la em toda a sua fragilidade. O corpo morto enquanto testemunho do poder da Lei, embora o resultado de sua morte tenha se mostrado contrário ao exemplo pretendido pelos diretores do asilo - náo se fez a ordem, mas se testemunhou para sempre a possibilidade da desordem: "A desordem que é, biologicamente, a podridão por vir, que, assim como o cadáver fresco, é imagem do destino, carrega em si mesma uma ameaça." (BATAILLE, 2014, p. 70). As feridas que se abriram no corpo do estrangeiro se estenderam ao corpo do asilo, por mais que os diretores pretendessem retomar o curso cotidiano de suas vidas, por mais que desejassem manter para-sempre o idílio da ordem: "Ergueu-se um grande catafalco na entrada, e os convidados ficaram para se juntar ao funeral. $\mathrm{O}$ sol brilhava agora luminoso. As flores do jardim, ainda meio orvalhadas, desabrochavam. A vegetação penetrava pelas janelas e se agitava nos quartos." (BLANCHOT, 1983, p. 56). Como se percebe nesse trecho da narrativa blanchotiana, a morte, o corpo supliciado, parece náo fazer parte do idílio, na verdade, não o faz, pois o corpo morto demarca o abjeto, o corrompido, a aliança com o Mal: "O lado do Bem é aquele da submissão, da obediência. A liberdade é sempre uma abertura à revolta, e o Bem está 
ligado ao caráter fechado da regra." (BATAILLE, 2015, p. 189, grifo meu). Diferente de um oásis em meio ao deserto, o idílio da ordem se desvela como uma miragem, uma falsa imagem que corrompe os sentidos, principalmente a visão, como já nos alertara o primeiro oráculo de "Lidylle": "Mas lhe peço, siga meu conselho: não confie nas aparências." (BLANCHOT, 1983, p. 9).

À semelhança do corpo morto do estrangeiro, a narrativa "Lidylle", em suas últimas palavras, passa também a se decompor, a desaparecer em diversos caminhos interpretativos - em uma sucessão convergente-divergente interpretativa que, contrariamente ao que em um primeiro momento poderia sugerir, não anula o pensamento, mas antes imprime nele uma força centrípeta que o leva a uma quase-pulverização, a uma quase-morte, pois a morte do estrangeiro não significa o prenúncio de um futuro melhor com o processo de ruína da Lei, e nem o de um futuro catastrófico com a presença da Lei e com o desaparecimento de Akim, e sim o esgarçamento de toda e qualquer possibilidade de interpretação, uma quase-fragmentação total do pensamento. Esse movimento em desastre de "L'idylle" resulta da aparente banalidade narrativa que, por instantes, omite o seu caráter realmente atordoador: a continuação do viver, na morte, dos demais personagens. Nesse sentido, a morte, em Blanchot, é o modo pelo qual o pensamento se estrutura e se desestrutura. A morte tanto é possibilidade quanto impossibilidade da literatura. Ou seja, diferente de seu significado no mundo real, a morte, no espaço literário, não é o fim, mas o fim enquanto recomeço no qual o recomeçar só é possível com o fim, com a morte - esse movimento, nos diz Blanchot, é intercambiável e inseparável: "Somente a morte me permite agarrar o que quero alcançar; nas palavras, ela é a única possibilidade de seus sentidos. Sem a morte, tudo desmoronaria no absurdo e no nada." (BLANCHOT, 1997, p. 312). Seguindo essa perspectiva, é a morte que faz a abertura - o corte, a ferida, o talho, o rasgo - final em "L'idylle", deixando em uma inconclusão, como a maioria dos textos kafkianos, o pensamento enquanto falta, perda, desviando-o para-sempre de uma verdade que o arrebataria. Em "Lidylle", a morte não traz uma resposta, mas múltiplas - todas elas possíveis em sua impossibilidade.

De um modo que ecoa o final aparentemente banal de $A$ metamorfose, de Kafka, o final de "Lidylle", de Blanchot, em sua quase-banalidade, deixa entrever, em sua simplicidade kafkiana, ${ }^{4}$ o quanto atordoante é sabermos que a

4 Em Kafka: pró e contra, Günther Anders destaca que na aparente banalidade ou na aparente simplicidade dos acontecimentos narrativos em Kafka se dissimula o verdadeiro horror presente em seus textos: "Em Kafka, o inquietante não são os objetos nem as ocorrências como tais, mas o fato de que seus personagens reagem a eles descontraidamente, como se estivessem diante de objetos e acontecimentos normais. Não é a circunstância de Gregor Samsa acordar de manhă transformado em inseto, mas o fato de não ver nada de surpreendente nisso - a trivialidade do grotesco - que torna a leitura táo aterrorizante." (ANDERS, 2007, p. 20). 
vida se faz a partir da morte, estando a morte presente na vida, sendo a morte a sua fundamentação existencial, o seu, digamos, viver. Em $A$ metamorfose, após o assassinato de Gregor Samsa por seu pai, que o acertara com uma maçã em suas costas, deliberando por sua vida como um representante da Lei, ${ }^{5}$ assim como deliberou Pierre em relação à vida do estrangeiro, a sua irmá assume o posto de provedora da família. Na verdade, essa substituição tão banal omite uma realidade das mais grotescas: juntamente com a morte, a vida perde o seu valor de mercado, embora seja a morte que reinsira novamente os pais de Gregor na sociedade por meio de sua filha. Dessa forma, para que a filha pudesse existir (viver) fora preciso Gregor morrer: "Enquanto conversavam assim, ocorreu ao senhor e à senhora Samsa, quase que simultaneamente, à vista da filha cada vez mais animada, que ela [...] havia florescido em uma jovem bonita e opulenta." (KAFKA, 1997a, p. 84-85). No texto "A leitura de Kafka”, de 1943, Blanchot escreve sobre a sua interpretaçáo da morte de Gregor, sobre o seu "fim": "não é verdade, não houve fim, a existência continua, e o gesto da jovem irmã, seu movimento de despertar para a vida, de apelo à volúpia sobre o qual a narrativa termina, é o cúmulo do terrível, não há nada mais apavorante em toda a novela." (BLANCHOT, 1997, p. 17). O pavor experienciado por um Blanchot-crítico sobre a morte enquanto existência do viver encontra o seu paralelo em um Blanchot-escritor quando, em 1983, em "Lidylle", mais uma vez a morte de um ser é o despertar para a vida de terceiros, embora esse despertar se mantenha inconcluso, inacabado, suspenso em sua vida-pela-morte. Eis o final de "Lidylle", citado anteriormente: "Ela [Louise] deu maquinalmente leves pancadinhas em seus joelhos [da exnoiva], depois, após ter observado o céu magnífico e maravilhoso, o céu que, sob o espelho da primavera, unia-a [a ex-noiva] ainda, apesar da morte e das lágrimas, aos reflexos de uma fé inquebrantável, ela se levantou para exercer seus deveres de dona da casa." (BLANCHOT, 1983, p. 56).

Por fim, se, por um lado, somos tomados de pavor ao terminar a leitura de "L'idylle", pois a morte de um ser é prontamente suplantada pelo ordinário da vida; por outro lado, a própria morte enseja esse movimento ordinário, pois ela também somente passa a existir quando a vida se movimenta e de seu movimento, que ela própria origina, resulta para todos a morte. Akim morreu, o seu corpo resta ao chão, depositário de uma (im)possibilidade de esperança para aqueles que ficaram, pois "[a agonia do herói] também representa uma esperança política e um sentido de continuidade da vida coletiva, uma capacidade para a fé mesmo nos momentos históricos mais sombrios, o que transcende qualquer mera fixaçáo individualista no protagonista."

5 Recomendo o meu artigo "Amerika, de Franz Kafka: de pai para filho", publicado na Revista Gragoatá, em 2018, para uma leitura mais cerrada sobre a Lei paterna nos escritos de Franz Kafka. Este artigo está disponível em: <https://periodicos.uff.br/gragoata/article/view/33565/19552>. 
(EAGLETON, 2013, p. 57). Porém, em se tratando de Blanchot, essa esperança política que se desenvolve em toda a escrita de "Lidylle" se demora como uma esperança enquanto esperança, esperança em seu sentido mais profundo, sem nunca deixar de ser esperança: "Existe esperança, se ela se relaciona longe de toda a apreensão presente, de toda a possessão imediata com aquilo que está sempre por vir, e que talvez não virá jamais; e a esperança proclama a vinda esperada daquilo que não existe ainda senáo como esperança." (BLANCHOT, 2001, p. 84). Um corpo morto que espera, em sua esperança, tornar-se aquilo que talvez ele espere: a destituição total da Lei do asilo. Uma esperança que, talvez, não seja nada mais do que a esperança daquilo que se revela como uma possibilidade com a morte de Akim: a morte da Lei. Contudo, se a morte é a própria vida, a perpetuação do viver dos seres, nem Akim e nem a Lei podem, de fato, morrer, muito menos, apenas viver, podem, quando muito, viver na morte ou morrer em vida: demoran $\mathrm{do}^{6}$ mortos-vivos.

\section{Referências}

ANDERS, Günther. Kafka: pró e contra. Tra. de Modesto Carone. São Paulo: Cosac Naify, 2007.

BATAILLE, Georges. O erotismo. Trad. de Fernando Scheibe. Belo Horizonte: Autêntica Editora, 2014.

BATAILLE, Georges. A literatura e o mal. Trad. de Fernando Scheibe. Belo Horizonte: Autêntica Editora, 2015.

BENJAMIN, Walter. Magia e técnica, arte e politica: ensaios sobre literatura e história da cultura. Trad. de Sérgio Paulo Rouanet. São Paulo: Brasiliense, 2012 - (Obras Escolhidas v. 1).

BLANCHOT, Maurice. Thomas l'obscur. Paris: Gallimard, 1941.

BLANCHOT, Maurice. Aminadab. Paris: Gallimard, 1942.

BLANCHOT, Maurice. L'arrêt de mort. Paris: Gallimard, 1948.

\footnotetext{
6 Gostaria de chamar a atenção para o verbo francês demeurer que, em português, pode ser traduzido, por exemplo, por demorar, permanecer, ficar ou residir. No entanto, em Blanchot, como bem destaca Jacques Derrida, em Demeure, tanto o verbo demeurer quanto o substantivo demeure [morada] passam a significar aquele ou aquela que se mantém sob o abrigo da morte, no abrigo do distanciamento que é a própria morte. Vejamos: delmeure, meure de meurt/mourir [morrer]. Ou seja, em "Lidylle", demorar é se manter abrigado sob a morte, manter-se vivo na morte, sob a morte, com a morte, por isso a Lei e Akim são espécies de mortos-vivos. E, mais uma vez, eles lembram os personagens de Kafka. Neste caso, o intrigante morto-vivo kafkiano, o caçador Graco, da narrativa "O caçador Graco", presente em Narrativas do espólio. A todo momento, Blanchot convida Kafka a participar de sua escrita, como um parceiro de escrita, como aquele que o convoca a escrever.
} 
BLANCHOT, Maurice. Celui qui ne m’accompagnait pas. Paris: Gallimard, 1953.

BLANCHOT, Maurice. Le dernier homme. Paris: Gallimard, 1957.

BLANCHOT, Maurice. Au moment voulu. Paris: Gallimard, 1979.

BLANCHOT, Maurice. "L'idylle". In: BLANCHOT, Maurice. Après coup précédé par Le Ressassement éternel. Paris: Les Éditions de Minuit, 1983.

BLANCHOT, Maurice. O espaço literário. Trad. de Álvaro Cabral. Rio de Janeiro: Rocco, 1987.

BLANCHOT, Maurice. A parte do fogo. Trad. de Ana Maria Scherer. Rio de Janeiro: Rocco, 1997.

BLANCHOT, Maurice. A conversa infinita 1 - a palavra plural. Trad. de Aurélio Guerra Neto. São Paulo: Escuta, 2001.

BLANCHOT, Maurice. La folie du jour. Paris: Gallimard, 2002.

BLANCHOT, Maurice. A conversa infinita 2 - a experiência limite. Trad. de João Moura Jr. São Paulo: Escuta, 2007.

CAMUS, Albert. L'étranger. Paris: Gallimard, 1942.

DERRIDA, Jacques. De l'hospitalité. Paris: Calmann-Lévy, 1997.

DERRIDA, Jacques. Demeure: Maurice Blanchot. Paris: Galilée, 1998.

EAGLETON, Terry. Doce violência: a ideia do trágico. Trad. de Alzira Allegro. São Paulo: Editora Unesp. 2013.

FOUCAULT, Michel. Vigiar e Punir: nascimento da prisão. Trad. de Raquel Ramalhete. Petrópolis: Vozes, 2014.

KAFKA, Franz. O Processo. Trad. de Modesto Carone. São Paulo: Companhia das Letras, 1997.

KAFKA, Franz. A Metamorfose. Trad. de Modesto Carone. São Paulo: Companhia das Letras, 1997a.

KAFKA, Franz. O Castelo. Trad. de Modesto Carone. São Paulo: Companhia das Letras, 2000.

KAFKA, Franz. “O caçador Graco”. In: KAFKA, Franz. Narrativas do espólio. Trad. de Modesto Carone. São Paulo: Companhia das Letras, 2002. p. 66-72.

KAFKA, Franz. O desaparecido ou Amerika. Trad. de Susana Kampff Lages. São Paulo: Editora 34, 2012.

LEVINAS, Emmanuel. Le temps et l'autre. Paris: PUF, 2011. 
PIMENTEL, Davi Andrade. “Amerika, de Franz Kafka: de pai para filho”. Gragoatá, Niterói, v. 23, n. 45, jan.-abr. 2018, p. 68-91. Disponível em: <https://periodicos. uff.br/gragoata/article/view/33565/19552>. Acesso em: 27 nov. 2020.

SARTRE, Jean-Paul. Aminadab, ou o fantástico considerado como uma linguagem. In: SARTRE, Jean-Paul. Situaçôes I: críticas literárias. Trad. de Cristina Prado. Sáo Paulo: Cosac Naify, 2005. p. 135-149.

SAUSSURE, Ferdinand de. Curso de Linguistica Geral. Trad. de Antônio Chelini, José Paulo Paes e Izidoro Blikstein. Sáo Paulo: Cultrix, 2006.

SCHWARZ, Roberto. A sereia e o desconfiado. Rio de Janeiro: Paz e Terra, 1981.

SHAHRJERDI, Parham. "Comment Blanchot serait-il possible? Iran: on tue une littérature”. In: Antelme, Monique; et al. Blanchot dans son siècle. Lyon: Sens Public; Éditions Paragon, 2009, p. 147-151.

Davi Andrade Pimentel é Pós-doutorando Sênior do Departamento de Ciência da Literatura da Faculdade de Letras da Universidade Federal do Rio de Janeiro. Pósdoutor pela Universidade Federal Fluminense. Doutor em Literatura Comparada pela Universidade Federal Fluminense. Trabalha atualmente com a tradução para o português de obras do escritor francês Maurice Blanchot, tendo publicado artigos relevantes para a área da tradução e para a difusão da obra blanchotiana no Brasil. Dentre estes, os mais recentes, publicados em 2020, são: "A tradução em tempos sombrios", publicado na Revista Cadernos de Tradução, v. 40 (UFSC); "Maurice Blanchot: reflexões (em desastre) sobre Aminadad", publicado na Revista Gragoatá, v. 25 (UFF); e "O sol na cabeça, de Geovani Martins: a literatura do morro", publicado na Revista $O$ eixo e a roda, v. 29 (UFMG).

E-mail: davi_a_pimentel@yahoo.com.br 